\title{
Guillaume Carré
}

Les marges statutaires dans le Japon prémoderne: enjeux et débats

La question des marges statutaires a émergé dans l'historiographie du Japon prémoderne (fin XVI ${ }^{\mathrm{e}}$-milieu du XIX ${ }^{\mathrm{e}}$ siècle) au cours des années 1990, dans le sillage de la remise en cause progressive d'une compréhension de la société d'ordres des Tokugawa conjuguant conceptions traditionnelles des statuts sociaux et schémas du matérialisme historique. Alors qu'on considérait jusqu'alors que la structure sociale du Japon prémoderne se composait de quatre statuts hiérarchisés (les guerriers, les paysans, les artisans, les marchands) et de parias, les recherches menées dans l'entourage de Yoshida Nobuyuki et de Tsukada Takashi ont montré que de larges pans de la population ne pouvaient être complètement assimilés à l'un de ces ordres canoniques. L'analyse de la variété des formes d'association des «groupes sociaux» de la période d'Edo et de leurs rapports avec leur environnement social et politique a conduit à reconsidérer la notion même de statut social à l'époque prémoderne, en renouvelant en profondeur l'histoire sociale de cette période et en ouvrant de nouveaux domaines d'investigation pour les chercheurs.

\section{Status margins in premodern Japan: issues and debates}

The issue of status margins emerged in the historiography on premodern Japan (late $16^{\text {th }}$-mid $19^{\text {th }} \mathrm{c}$.) after a progressive reconsideration of the prevalent view of the Tokugawa society, a combination of traditional conceptions of social statuses and historical materialism. Until then, the social structure of premodern Japan was understood as a hierarchy of four statuses (warriors, peasants, artisans, and merchants), with pariahs outside that system. Yet research led by Yoshida Nobuyuki and Tsukada Takashi has shown that large numbers of the population could not be assimilated to any of those orders. The analysis of the diversity of associative forms of "social groups", and their relations to their political and social environments, during the Edo era unsettles the very notion of social status in premodern Japan, opening new lines of historical enquiries.

\section{Morishita Tôru}

Les guerriers et leurs domestiques dans la ville seigneuriale de Hagi

La société du Japon de l'époque d'Edo était dominée par les guerriers (bushi), regroupés dans des villes sous la surveillance de leurs seigneurs, les daimyô. Ces guerriers, coupés de toute activité productive agricole ou artisanale, ou du commerce, vivaient de l'exploitation 
du travail des paysans et entretenaient une nombreuse domesticité. L'historiographie s'est longtemps interrogée sur la place de ces valets de guerriers dans la société des Tokugawa: étaient-ils aux derniers échelons de la condition guerrière ou devaient-ils être assimilés à la masse des domestiques employés par le reste de la population? L'étude du cas du fief de Hagi montre que la domesticité guerrière était en réalité intimement liée au fonctionnement des vasselages et au prestige de la condition des bushi. Quoiqu'étant des travailleurs sans qualification et à l'origine sans patrimoine, les valets n'en recherchaient pas moins des moyens de sécuriser des positions avantageuses qu'ils avaient pu obtenir, en subvertissant ainsi les hiérarchies sociales.

\section{Warriors and their servants in the fief city of Hagi}

Edo-era Japan was dominated by warriors (bushi), living in groups in cities under the watch of their lords (daimy $\hat{o}$ ). Those warriors did not partake in any productive or commercial activity, but lived off the peasants' work and had a vast number of servants at their employ. The historiography has long pondered the exact role of these warriors' servants in the Tokugawa society. Were they at the bottom of the warrior group or should they be considered as part of the servant class as those working for different employers? The study of the Hagi fief shows that they were in fact an integral part of the vassalage system and the prestige enjoyed by bushi. Although without special skills nor personal property at the start, those servants had advantageous positions they sought to secure, subverting in the process the social hierarchies that had created them.

\section{Yoshida Nobuyuki}

Espace urbain et corporations

Les associations de coiffeurs dans le Japon d'Edo

À l'époque d'Edo, la reconnaissance d'un statut social était théoriquement la contrepartie d'une capacité à soutenir l'exercice de l'Autorité publique (le pouvoir guerrier) par l'accomplissement de services. Mais pour une multitude de petits métiers artisanaux exercés par des populations précaires et quasiment dépourvues de patrimoine, cette reconnaissance n'allait pas de soi, car les autorités ne considéraient pas ces activités avec beaucoup d'intérêt, sinon pour des questions de maintien de l'ordre. Les coiffeurs d'Edo mirent ainsi des années pour faire avaliser par les préfectures de la ville leurs organisations professionnelles qui régissaient l'exercice de la profession et protégeaient les intérêts de leurs membres. Ces associations n'étaient cependant pas exemptes de contradictions et de conflits internes, qui témoignent d'une évolution du métier de coiffeurs aboutissant à une dissociation entre un droit d'exercice de la profession, objet de transaction, et la pratique réelle des soins capillaires.

\section{Status margins in Edo-era Japan: barbers' associations}

In the Edo era, a social status was theoretically based on the ability to support the exercise of public authority (i.e. the warriors) through the delivery of services. But for a multiplicity of small crafts done by unstable populations with little property, to have their social status acknowledged by the authorities was difficult. The Edo barbers spent years having their professional associations certified by the city prefectures, to regulate their trade and 
protect the interests of their members. Those organizations were not free of contradictions and internal conflicts, triggered by evolutions of the trade that led to a dissociation between the right to exercise the trade and its actual practice.

\section{Yoshida Yuriko}

\section{Artistes ou marginaux? \\ Les sasara de Shinano}

Les sasara du sud de la province de Shinano (actuel département de Nagano) étaient une population d'artistes itinérants donnant des spectacles dans plusieurs régions du pays, surtout à l'occasion des fêtes du Nouvel An. Ils étaient obligés d'accomplir dans leurs communautés villageoises de résidence des tâches considérées comme avilissantes par le reste des habitants et y subissaient des discriminations plus ou moins importantes. Pourtant, ces sasara avaient une forte conscience de leur statut et cherchaient à tout prix à se distinguer d'autres groupes qu'ils considéraient comme plus dégradés qu'eux, tels les hinin. C'est pourquoi ils se firent patronner par une institution religieuse, le temple du Mii-dera, et cherchèrent à tirer parti de son prestige pour sécuriser leur position sociale et leurs intérêts. Les sasara n'en restaient pas moins un groupe social à la personnalité ambiguë, à la limite du monde des gueux, de celui des artistes et de celui des religieux mendiants.

\section{The sasara of Shinano: a local society and its marginalized artists}

In the south of the Shinano province (in present-day Nagano Prefecture), the sasara were a group of itinerant artists giving shows in several parts of the country, especially during the New Year festivities. Wherever they resided, they were compelled to perform tasks considered as demeaning by the population, and were the butt of small or big acts of discrimination. Yet the sasara had a strong sense of their status and kept distinguishing themselves from other groups they deemed inferior, such as the hinin. That is why they obtained the patronage of a religious institution, the Mii-dera temple, and used it to try and secure their social position and interests. Yet they remained an ambiguous social group, at the edges of the worlds of beggars, artists, and mendicant orders.

\section{Tsukada Takashi}

\section{Les religieux mendiants d'Ôsaka durant la période prémoderne}

Le formidable développement urbain du Japon au XVII ${ }^{\mathrm{e}}$ siècle provoqua la prolifération de populations de mendiants que les autorités guerrières des cités cherchèrent à contrôler. Dans le cas d'Ôsaka, certains groupes discriminés et relégués dans des ghettos, les hinin, avaient fait de la mendicité leur principale activité professionnelle. Mais il existait d'autres types de quêteurs qui prenaient un prétexte religieux pour recueillir les aumônes, parfois en se livrant à diverses performances. Ces individus réduits à la mendicité, mais qui n'étaient pas à l'origine issus de groupes discriminés, étaient en concurrence les uns avec les autres pour capter la charité des citadins. Aussi, bien qu'écartés en apparence de toute forme de propriété, ces individus cherchaient parfois à se regrouper et à former des associations sous le patronage d'une institution religieuse reconnue, afin de défendre leurs intérêts et de les faire reconnaître par les autorités de la ville, soucieuses de leur côté de mieux encadrer ces populations suspectes. 


\section{Religious mendicants in premodern Osaka}

The tremendous urban development in $17^{\text {th }}$ century Japan led to the proliferation of beggars that the authorities sought to control. In the case of Osaka, some discriminated groups, relegated into ghettos -the hinin- had turned to begging as their main livelihood. But there were also other who used religious pretext to ask for alms, sometimes in exchange of various performances. Those individuals generally came from respectable groups but had been reduced to begging, and were in competition with others for the charity of citizens. They sometimes sought to consolidate their position by forming associations under the patronage of religious institutions, to defend their interests with the city authorities, that in turn used it to better control this suspicious population. 